\title{
Diversity, distribution and seasonal variations of grasshopper populations in Sialkot, Punjab, Pakistan
}

\author{
Mubashar Hussain*, Robina Akbar, Muhammad Faheem Malik, Syeda \\ Nafeesa Kazam and Tamkeen Zainab \\ Department of Zoology, Faculty of Science, University of Gujrat, 50700, Punjab- Pakistan \\ *Corresponding author's e-mail: $\underline{\text { dr.mubashar@uog.edu.pk }}$ \\ Citation \\ Mubashar Hussain, Robina Akbar, Muhammad Faheem Malik, Syeda Nafeesa Kazam and Tamkeen Zainab. \\ Diversity, distribution and seasonal variations of grasshopper populations in Sialkot, Punjab, Pakistan. Pure and \\ Applied Biology. Vol. 6, Issue 4, pp1372-1381. http://dx.doi.org/10.19045/bspab.2017.600148
}

Received: 07/07/2017

Revised: 19/10/2017

Accepted: $26 / 10 / 2017$

Online First: 30/10/2017

\section{Abstract}

The study was planned to estimate diversity, distribution and seasonal variations of grasshoppers in croplands of Sialkot, Punjab, Pakistan. The seasonal variations were assessed by sampling 16 randomly selected sites fortnightly during 2015-2016. The specimens were collected by hand picking and using sweep net. Adult grasshoppers were sampled from each site between 10:00 and 15:00 PST under sunny conditions. The collected specimens were killed, identified and preserved. Data were subjected to statistical analysis and interpretations which indicate the presence of 18 species representing 14 Genera, 8 subfamilies and 3 families. The collected specimens represented sub-family Acridinae (genus Acrida) which were found to be the most abundant (372) followed by sub-family Oxyinae (genus $O x y a$ ) with 330 specimens whereas their population was consistent in all study sites. Data indices calculated showed greater richness and evenness of species in the studied area. The higher value of Shannon Index (2.722) showed that greater richness and the evenness of species in the sampled areas. Simpson Index value (0.927) showed dominance in terms of more species diversity. Oxya hyla, Oxya japonica and Hieroglyphus banian were the most abundant species whereas Mermiria bivittata was the least common species. Maximum populations were recorded during July-November $(61.39 \%)$ with an increasing trend in population size during these months indicating seasonal variations in their populations around the year. The study suggested that sampled area has well established grasshopper populations which require well-knitted pest management strategies to avert economic losses and conserve biodiversity.

Keywords: Orthoptera; Hieroglyphus; Acrididae; Biodiversity; Rice pests

\section{Introduction}

Sialkot is recognized as an industrial as well as an agricultural city of Pakistan containing about 3.5 million populations and ranked as $6^{\text {th }}$ largest city of Pakistan. The agricultural productivity in this rice dominated farming system has been threatened due to floods, unexpected rains, industrialization, urbanization and pest infestations. The changes in agricultural land usage practices, cropping patterns and expansions are mainly due to urbanization and industrialization which affects the seasonal distribution patterns of grasshoppers [1]. Geographical 
conditions of Pakistan provide ideal breeding places for grasshoppers which, thus, pose serious threats to crops and pastures both in irrigated fields and rain-fed areas [2]. Grasshoppers as major pests of many crops and grasslands, occupy almost all terrestrial habitats and climates are best known for their great potential to damage crops [3].

Landscape structure, changing environmental conditions, cropping patterns and farming systems greatly influenced the distribution and variety of the grasshopper species in different parts of world [4]. Grasshoppers are the most important natural herbivore in the prairies that intermittently leads to widespread destruction of grasslands and croplands [5]. As they have the ability to adapt in varying conditions of moisture, flora at different times and locations [6].

In Pakistan various researchers worked on the crop pests and reported grasshoppers as pests of paddy fields [7, 8]. In different studies, conducted at Mir Pur [9] and Multan [10], 25 and 21 species of grasshoppers were reported to feed on various species of crops. A comprehensive survey was conducted during 2003-2004 which covered major districts of Pakistan and reported the diversity of species at different locations with variations in their spatio-temporal occurrence [11]. The diversity of grasshoppers in Bhimber District represented 25 species belonging to 02 families with Oxya hyla as most dominated species [12]. Similar survey on grasshoppers conducted at 18 selected places in Jammu and Kashmir reported 16 species of subfamily Oedipodinae belonging to 13 genera [13]. The abundance and diversity of grasshoppers provides ecological status and valuable information about composition of the pest species with reference to crops and seasons, thus, can be utilized effectively in pest management programs [14]. The perusal of literature indicated that faunal exploration of Orthoptera has not been carried out in the proposed habitat during recent years despite its immense significance in pest management and biodiversity studies. Keeping in view, the importance of exploring the grasshopper fauna, this study was undertaken with main focus on diversity, distribution, abundance and seasonal variations of grasshoppers' population in district Sialkot. It provided valuable information about composition of the pest species with reference to crops and seasons thus can be utilized effectively in pest management programs.

\section{Materials and methods}

This study has been done to evaluate the abundance, diversity and distribution of grasshoppers in district Sialkot, Punjab, Pakistan. Sialkot city is located in $32^{\circ}$ to $30^{\prime}$ of North latitude, $74^{\circ}$ to $31^{\prime}$ of East latitude and $256 \mathrm{~m}$ above the sea level. The sampling and data collection was conducted from grasslands and croplands of District Sialkot. It is subtropical city and has seasonal variations in temperature (Mean $23.6{ }^{\circ} \mathrm{C}$ ) during summer and winter months with annual rainfall of about $772 \mathrm{~mm}$ dominated in moon soon season. A preliminary survey was carried out to select sampling sites within the study area and 16 study sites were selected to determine the diversity, distribution and abundance of grasshoppers.

\section{Study area}

The sampling area comprised of 16 randomly selected sites in Sialkot, Punjab, Pakistan representing croplands in rice-wheat dominated cropping system (Figure 1) comprised of Kot Maharaj (latitude $32.542 \mathrm{~N}$, longitude 74.351E), Jatheke (latitude $32.491 \mathrm{~N}$, longitude is $74.327 \mathrm{E}$ ), Bopal Wala (latitude 32.429N, longitude $74.363 \mathrm{E}$ ), Malkhanwala (latitude $32.445 \mathrm{~N}$, longitude 74.316E), Majra Kalan (latitude 32.531N, longitude 74.336E), Kot Dina (latitude $32.5178 \mathrm{~N}$, longitude $74.298 \mathrm{E}$ ), Begowala (latitude 32.439N, longitude 74.269E), Randeer Morr (latitude 32.470N, longitude 74.271E), Kotli Noonan (latitude 
32.447N, longitude 74.354E), Miran Pindi (latitude $32.533 \mathrm{~N}$, longitude 74.345E), Hamboke (latitude $32.546 \mathrm{~N}$, longitude 74.359E), Sahowala (latitude 32.456N, longitude 74.409E), Kuthiala (latitude
$32.554 \mathrm{~N}$, longitude 74.289E), Roras (latitude $32.509 \mathrm{~N}$, longitude 74.399 , Adamke Cheema (latitude $32.381 \mathrm{~N}$, longitude 74.357E), and Lopowali (latitude 32.489N, longitude 74.378E).

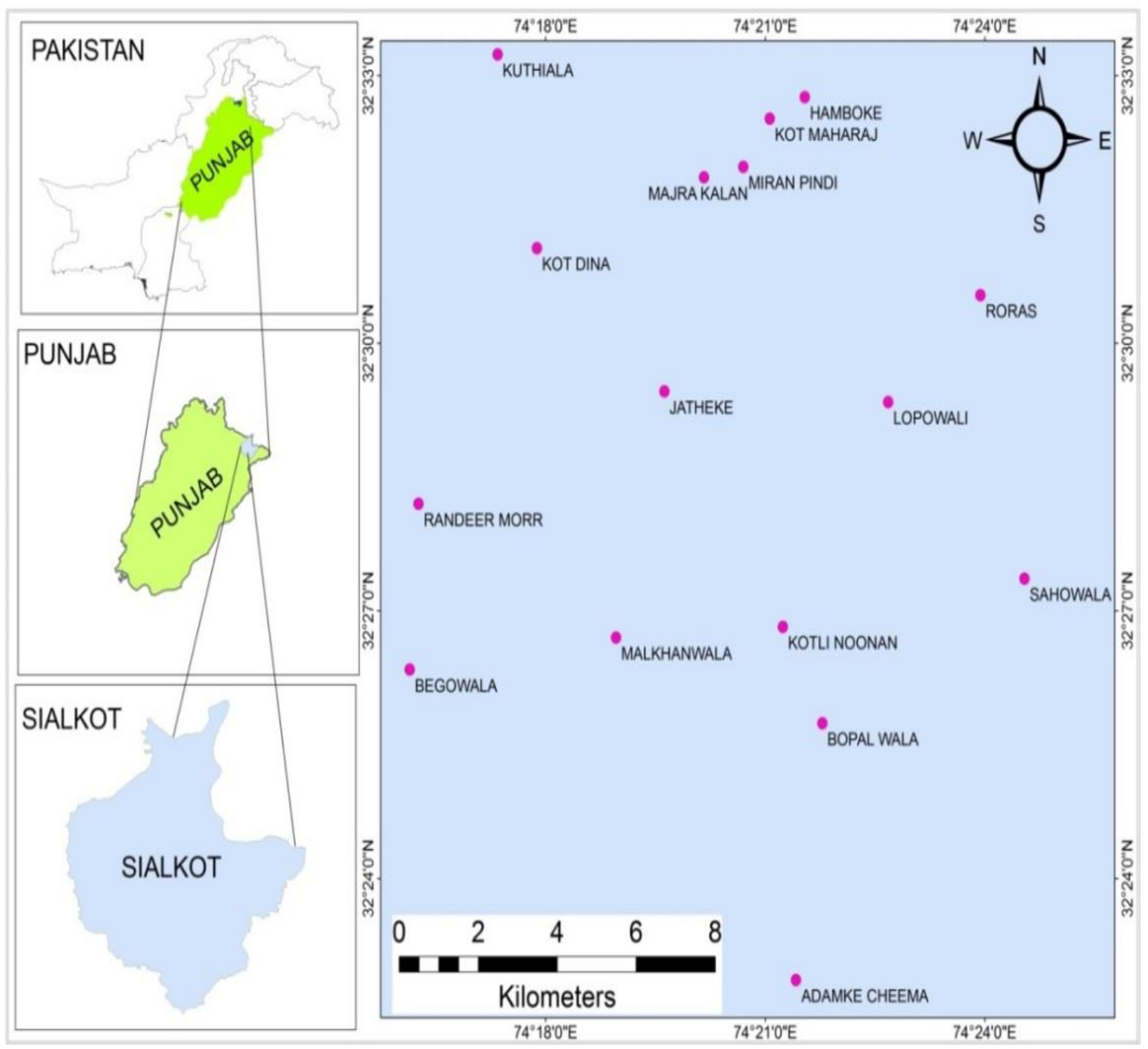

Figure 1. Map showing 16 randomly selected sampling sites in Sialkot, Punjab, Pakistan

\section{Sampling procedure}

The specimens were collected by hand picking [15] and using sweep net [16] from selected sites fortnightly from July 2015-June 2016. Adult grasshoppers were sampled from each site between 10:00 and 15:00 PST under sunny conditions to maximize the probability of detecting different species @ 250 net sweeps each sampling site to give uniformity in sampling[17].The collected specimens were killed, identified and preserved in wooden box[18]. 


\section{Taxonomic identification}

The specimens were examined under Leica MZ6 microscope. Taxonomic literature, internet sources and identification keys were explored to identify the specimens [19-25]. The taxonomic terminology was adopted to proceed for morphological identification process and confirmation of species identification [26-28]. The identified collection was deposited in the Laboratory of Systematics and Pest Management, Department of Zoology, University of Gujrat.

\section{Data analysis}

The data collected from different sites within the study area were subjected to analysis by applying various ecological indices i.e. Shannon-Wiener index and Simpson Index, to find out the diversity, distribution, abundance and richness [29].To describe grasshopper species and give comparative account of species on different sites and indices were calculated by Shannon-Weaver index $\left(H^{\prime}\right)$, Simpson's diversity index $(D)$. Species abundance was determined as the abundance of a given species relative to the total abundance of all species. Species richness was calculated by considering the total number of species found in the study sites [30].

\section{Results and discussion}

An assemblage of 1349 specimens belonging to 18 species was collected from 16 different sites sampled during 2015-2016. The data showed that $O$. hyla (189), Hieroglyphus banian (179), O. japonica (141), A. gigantea (126), A. turrita (125), D. japonica (104) were most abundant species whereas Trilophidia annulata (15), M. bivittata (9) were least abundant (Table 1). The data indicated that the six (06) species were more abundant in almost all sampling sites within study area i.e. $O$. hyla, $H$. banian, $O$. japonica, A. turrrita, A. gigantea, D. japonica whereas nine (09) species were less common and three (03) species were least common and rarely found in selected study sites (Table 1). Different index values depicted that sampled populations of grasshoppers present more diversity, richness and evenness of species in the selected areas of Sialkot (Table 2). This indicated that species are evenly distributed in the selected area with plenty of foraging available for their populations to grow during different seasons. Most abundant species was $O$. hyla whereas minimum value for diversity was shown by $M$. bivittata. Acrididae was represented by 14 species, Tettigoniidae by 2 species and Pygromorphoidae by 2 species. Remaining species belonged to 8 subfamiles (Table 3). The data collected from different sites showed variations in the population size of grasshoppers. Among the 1349 collected specimens, the highest number of specimens were recorded from Kot Maharaj (126) followed by Jatheke (115) and Malkhanwala (100) (Figure 2). Maximum specimens were collected during September (235) followed by August (200) and October (185) whereas lowest number of specimens were collected in the month of January (48) followed by February (53). The data showed increasing trend in the abundance of species from May to September (Figure 3).

The species collected from croplands showed variations in species diversity and richness with greater values of evenness that may be due to availability of diverse vegetation during different seasons. However variations in the population size of different species during different months of the year may also be attributed to climatic factors that determine population size. Our results correspond with the findings of earlier workers, positive association between plants and grasshoppers in semi-arid lands [31, 32]. However, contrary results were also reported in a study showing there is no influence of plants on grasshoppers' population [33]. During the rains in moon soon greater population was recorded from the study area showing greater differences in population 
abundance from other seasons. The rainfall may also be an important factor playing positive role in diversity of grasshoppers during rainy season [34]. In recent studies, Oxya genus associated with rice ecosystem was reported maximum and considered as pest of rice [35]. In studies conducted in Bhimber, diversity of grasshoppers was studied and $O$. hyla was found as the most abundant species [36]. Two genera as Oxya and Acrida in rice vegetation were found abundant [37]. We found species abundance in different sites of Sialkot that may be attributed to the vegetation and crops found in Sialkot. Majority of family Acrididae that found in rice crop is pest. The diversity, distribution and abundance of certain species in different seasons and sites were not varied within two years [38].Studies have shown that grasshopper species presented variations in seasonal abundance [39]. Acrida and Oxya were found dominant in studies conducted from croplands in Poonch Division, AJK [40].

Seasonal variations in environmental factors can change biochemical conformation and dietary significance of plants, thus, responsible for substituting the herbivores to other plants of that area, thus, providing more chances to grow on alternative foods available. This helps the grasshoppers to shift from one crop or plant type to another inflicting considerable damage to new hosts. Therefore, in areas dominated by one kind of plantation in a particular season, like Sialkot, favors certain type of fauna such as grasshoppers by providing plenty of food and breeding environment. Large number of grasshoppers was collected in the month of July, August, September and October that showed greater diversity and abundance that may be associated with plenty of food available during rainy season [41].

Table 1. Menhinick and fisher_alpha values for different species recorded from selected sampling sites in Sialkot, Punjab, Pakistan

\begin{tabular}{|l|c|c|c|}
\hline \multicolumn{1}{|c|}{ Species } & Abundance & Menhinick & Fisher_alpha \\
\hline Acrida exaltata & 27.00 & 00.19250 & 0.2045 \\
\hline Acrida gigantea & 126.0 & 0.089090 & 0.1482 \\
\hline Acrida turrita & 125.0 & 0.089440 & 0.1484 \\
\hline Acrida ungarica & 36.00 & 00.16670 & 0.1906 \\
\hline Atractomorpha crenulata & 43.00 & 00.15250 & 0.1830 \\
\hline Chortophaga viridifasciata & 33.00 & 00.17410 & 0.1946 \\
\hline Dittopternis venusta & 66.00 & 00.12310 & 0.1672 \\
\hline Ducetia Japonica & 104.0 & 00.09806 & 0.1533 \\
\hline Hieroglyphus banian & 179.0 & 00.07474 & 0.1397 \\
\hline Melanoplus bivittus & 61.00 & 00.12800 & 0.1699 \\
\hline Mermeria bivitata & 09.00 & 00.33330 & 0.2878 \\
\hline Neoconocephalus triops & 73.00 & 00.11700 & 0.1639 \\
\hline Oxya hyla & 189.0 & 00.07274 & 0.1385 \\
\hline Oxya japonica & 141.0 & 00.08422 & 0.1454 \\
\hline Phlaeoba panteli & 58.00 & 00.13130 & 0.1716 \\
\hline Poekilocerus pictus & 44.00 & 00.15080 & 0.1821 \\
\hline Shistocera alutacea & 20.00 & 00.22360 & 0.2215 \\
\hline Trilophidia annulata & 15.00 & 00.25820 & 0.2412 \\
\hline
\end{tabular}


Table 2. Diversity, abundance, dominance, evenness and richness of species sampled in croplands of Sialkot, Punjab, Pakistan

\begin{tabular}{|l|c|c|c|c|c|c|}
\hline & Species & Lower & Upper & Abundance & Lower & Upper \\
\hline Taxa_S & 18 & 18 & 18 & 18 & 18 & 18 \\
\hline Individuals & 171 & 171 & 171 & 1349 & 1349 & 1349 \\
\hline Dominance_D & 0.07212 & 0.06918 & 0.08567 & 0.08481 & 0.0813 & 0.09003 \\
\hline Simpson_1-D & 0.9279 & 0.9143 & 0.9308 & 0.9152 & 0.91 & 0.9187 \\
\hline Shannon_H & 2.722 & 2.612 & 2.755 & 2.633 & 2.591 & 2.66 \\
\hline Evenness_e^H/S & 0.8451 & 0.7569 & 0.8736 & 0.7729 & 0.7412 & 0.7945 \\
\hline Brillouin & 2.538 & 2.435 & 2.568 & 2.597 & 2.556 & 2.624 \\
\hline Menhinick & 1.376 & 1.376 & 1.376 & 0.4901 & 0.4901 & 0.4901 \\
\hline Margalef & 3.306 & 3.306 & 3.306 & 2.359 & 2.359 & 2.359 \\
\hline Equitability_J & 0.9418 & 0.9036 & 0.9532 & 0.9109 & 0.8964 & 0.9204 \\
\hline Fisher_alpha & 5.075 & 5.075 & 5.075 & 2.935 & 2.935 & 2.935 \\
\hline Berger-Parker & 0.1053 & 0.09942 & 0.1579 & 0.1401 & 0.1282 & 0.1594 \\
\hline
\end{tabular}

Table 3. Species reported from study area during 2015-2016 from Sialkot, Punjab, Pakistan

\begin{tabular}{|c|c|c|c|}
\hline Species & Sub-family & Family & $\begin{array}{c}\text { Abundance } \\
(\%)\end{array}$ \\
\hline Acrida exaltata (Wa1ker,1859) & Acridinae & Acrididae & 02.00 \\
\hline Acrida gigantea (Herbst, 1794) & Acridinae & Acrididae & 09.34 \\
\hline Acrida turrita (Linnaeus, 1758) & Acridinae & Acrididae & 09.27 \\
\hline Acrida ungarica (Herbst, 1786) & Acridinae & Acrididae & 02.67 \\
\hline Chortophaga viridifasciata (De Geer, 1773) & Oedipodinae & Acrididae & 02.45 \\
\hline Dittopternis venusta (Walker, 1870) & Oedipodinae & Acrididae & 04.89 \\
\hline Hieroglyphus banian (Fabricius, 1798) & Conocephalinae & Acrididae & 13.27 \\
\hline Melanoplus bivittatus (Say, 1825 & Melanoplinae & Acrididae & 04.52 \\
\hline Oxya hyla (Serville, 1831) & Oxyinae & Acrididae & 14.01 \\
\hline Oxya japonica (Thunberg, 1824) & Oxyinae & Acrididae & 10.45 \\
\hline Phlaeoba panteli (Bolivar, 1902) & Acridinae & Acrididae & 04.30 \\
\hline Shistocera alutacea (Stal, 1873) & Cyrtacanthacridinae & Acrididae & 01.48 \\
\hline Trilophidia annulata (Thunberg, 1815) & Oedipodinae & Acrididae & 01.11 \\
\hline Mermiria bivittata (Serville) & Gomphocerinae & Acrididae & 00.67 \\
\hline Atractomorpha crenulata (Fabricius, 1793) & Pyrgomorphinae & Pygromorohidae & 03.19 \\
\hline Poekilocerus pictus(Fabricius, 1775) & Pyrgomorphinae & Pygromorohidae & 03.26 \\
\hline Ducetia japonica (Thunberg, 1818) & Phaneropterinae & Tettigonidae & 07.71 \\
\hline Neoconocephalus triops (Linnaeus, 1758) & Conocephalinae & Tettigonidae & 05.41 \\
\hline
\end{tabular}




\section{Number of Specimens From Different Sites}

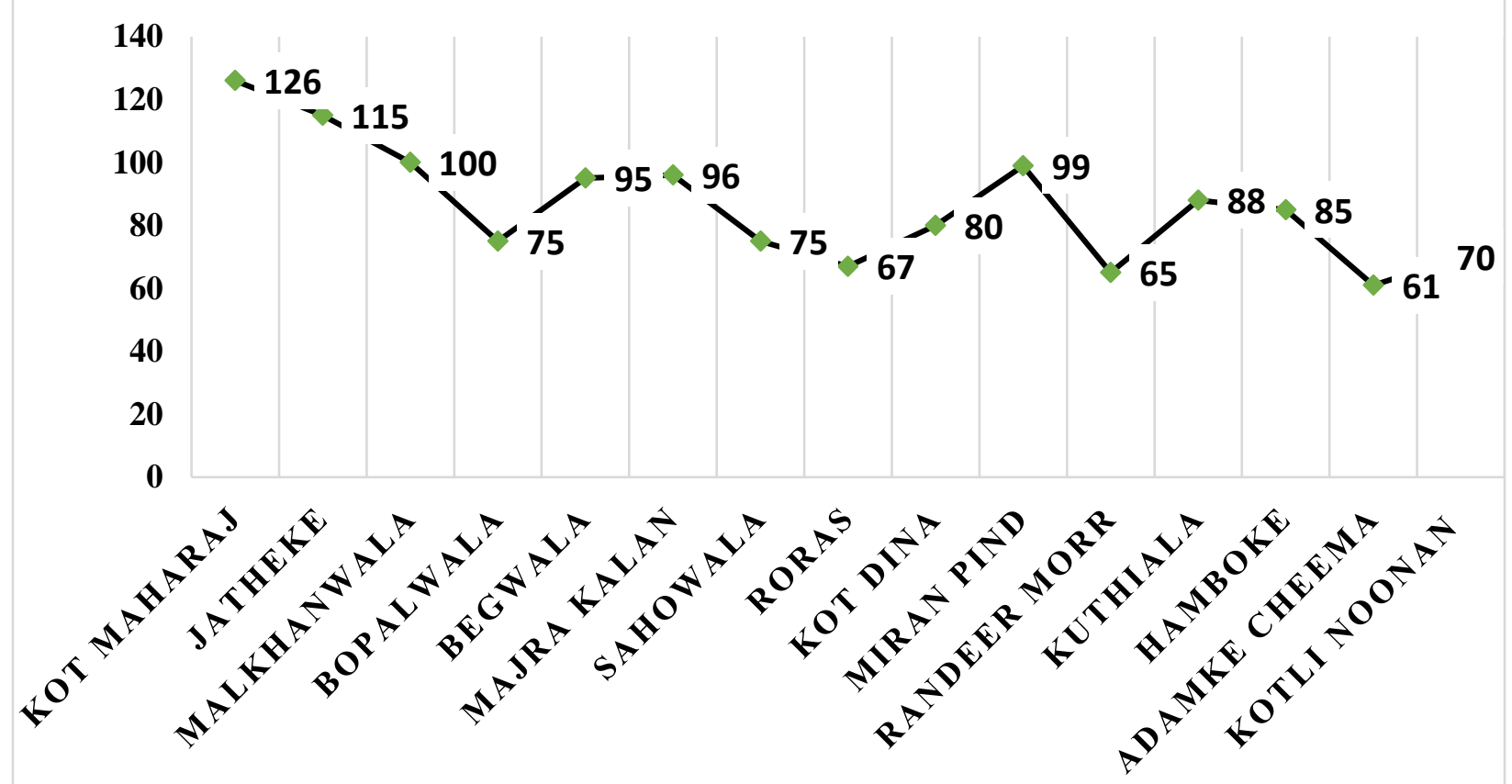

Figure 2. Number of specimens collected from different sites from croplands of Sialkot, Punjab, Pakistan

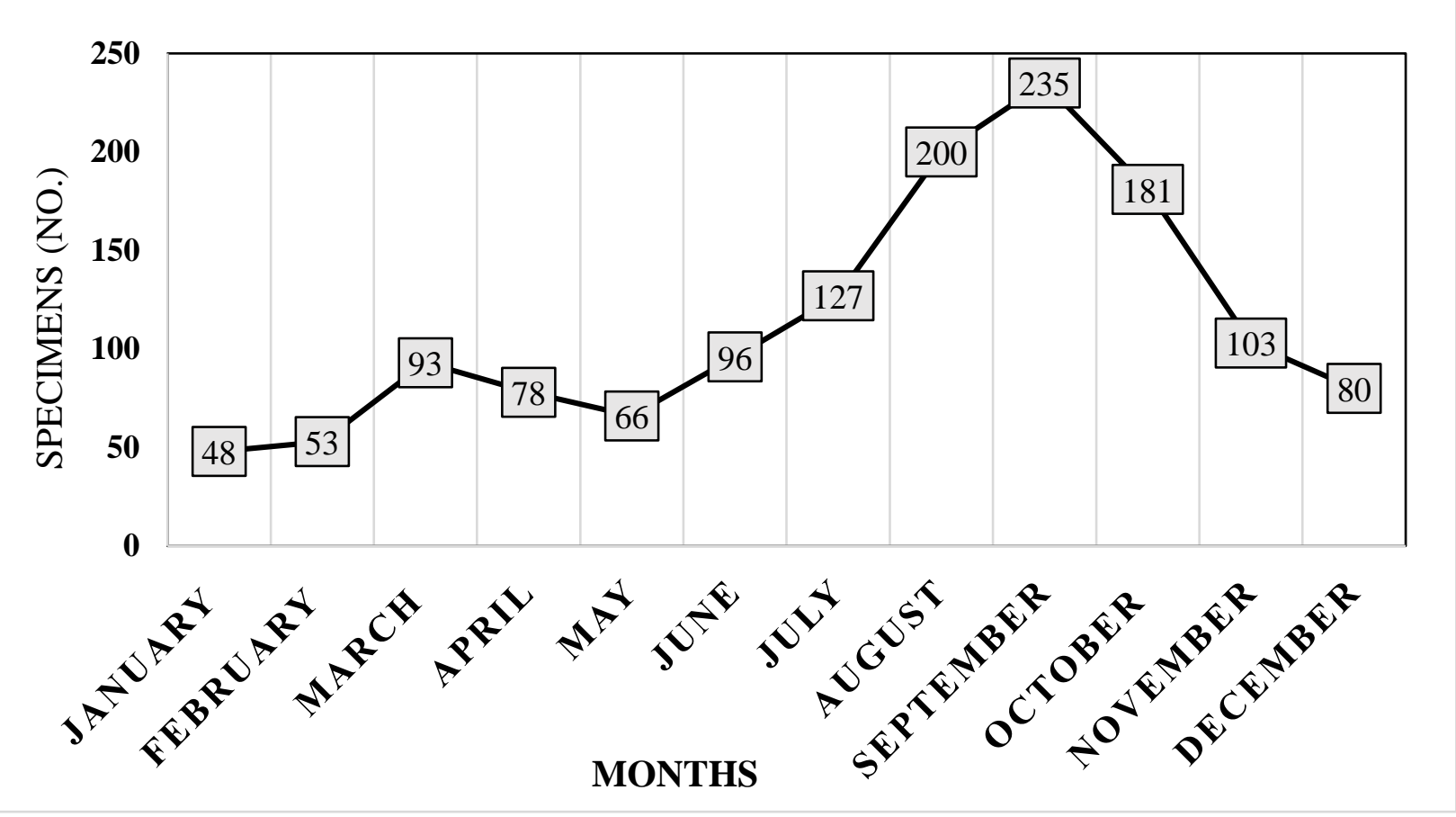

Figure 3. Number of specimens collected during different months from croplands of Sialkot, Punjab, Pakistan 


\section{Conclusion}

The present study was conducted to estimate diversity, distribution and seasonal variations of grasshopper species in Sialkot, Punjab, Pakistan during 2015-2016. A total number of 1,349 specimens of grasshoppers were collected from study sites which illustrated that maximum number of specimens belongs to sub-family Acridinae $(27.58 \%)$ dominated by genus Acrida. A.gigantea and A. turrita. Maximum number of species belonged to family Acrididae containing 14 species followed 02 species belonged to Tettigonidae and Pyrgomorphoidae each. Thus, it was the most important family in the studied area associated with cropland vegetation. Data on species abundance showed that $O$. hyla (14.01\%) followed by $H$. banian (13.27 $\%)$, O. japonica (10.45\%) and A. gigantea $(9.34 \%)$ were dominated the most of the sites whereas and $M$. bivittata was least abundant species $(0.67 \%)$. The study revealed that Sialkot is rich in grasshopper diversity with some species are more dominant than others. The abundance and composition of species indicated their seasonal variations where more abundant species were recorded during JulyNovember (835) whereas least abundance was found during December-February (181). The study revealed that Sialkot is rich in grasshopper diversity with some species are more dominant than others. The pest species associated with rice crops were more dominating and abundant in croplands.

\section{Authors' contributions}

Conceived and designed the experiments: M Hussain, Performed the Experiments: R Akbar, Analyzed the data: M Hussain \& MF Malik, Contributed reagents/materials/ analysis tools: R Akbar, Wrote the paper: SN Kazam \& T Zainab.

\section{References}

1. Pareek A, Sharma US, Lekha and Kalyan R (2017). Species richness, density and diversity of acrididae in maize ecosystem in southern
Rajasthan. J Entomol. Zoo. Studies 5(2): 746-749

2. Soomro S and Wagan MS (2005). Notes on Subfamily Calliptaminae (Acrididae: Acridoidea : Orthoptera) of Pakistan, with the Description of one New Species. Pakistan J Zool 37(3): 229-236, 2005.

3. Emosairue SO (2007). Fundamentals of Agriculture Entomology, $1^{\text {st }}$ Ed. Ethiope Publishing Corporation; Benin.

4. Shishodia MS, Chandra K \& Gupta SK (2010). An Annotated checklist of Orthoptera (Insecta) from India. Rec. Zool. Surv 14: 1-366.

5. Qureshi R \& Bhattim GR (2006). Ethnobotinanical observation of Achyransthes aspera Linn \& Aeriva $s p p$, with special reference to the people of Nara desert. Ham medi 1: 4348.

6. Cigliano MM, Wysiecki DML \& Lange C (2000). Grasshopper (Orthoptera, Acrididae) Species Diversity in the Pampas, Argentina. Diversity and Distributions 6:81-91.

7. Arya M, Joshi K \& Badon P (2015). Studies on Taxonomy, Distribution, Ecology and Behaviour of Grasshoppers (Insecta: Orthoptera) in Nanda Devi Biosphere Reserve, Western Himalayas, India. An Intern J Biol Forum7: 591 -598.

8. Usmani MK, Akhtar MH, Nayeem MR \& Rafi U (2012). Diversity, Distribution and Taxonomic Studies of Grasshopper Fauna (Acrididae: Acridoidea: Orthoptera) of Aligarh, Uttar Pradesh, India. J Annals of Ento 30: 31-40.

9. Rafi U \& Usmani MK (2013). Diversity and distribution of Acridid pests (Orthoptera: Acridoidea) of Purvanchal region, Uttar Pradesh. $J$ Bombay Natur Hist Soci 110(1): 50-56.

10. Mahmood K, Tamkeen A, Mahmood Z \& Rehman Z (2011). Grasshopper Species Composition in Mirpur Division of Azad Jammu and Kashmir, 
Pakistan. Pakistan J Zool 43(2): 223227.

11. Zafar M (2015). Prevalence and Economic Importance of Grasshoppers and their Allies associated with foods. Biol Pak 0006 - 3096 (Print) 61: 189199.

12. Sultana R, Wagan AS \& Wagan MS (2012). Effects of Macro-Parasitic mite Eutrombidium trigonum (Hermann) on the life History Characteristics of Hieroglyphus species from Sindh, Pakistan. African $J$ of Microbio Res, 6(19): 4158-4163.

13. Tamkeen A, Mahmood K, Mahmood Z \& Rehman Z (2011). Grasshopper Species Composition in Mirpur Division of Azad Jammu and Kashmir, Pakistan. Pak J Zool 43: 223-227.

14. Sun T, Liu ZY, Qin, LP and Long RJ (2015). Grasshopper (Orthoptera: Acrididae) Community Composition in the Rangeland of the Northern Slopes of the Qilian Mountains in Northwestern China. J Insect Sci 15(1), http://doi.org/10.1093/jisesa/ieu171

15. Tamkeen A, Mahmood M \& Nazir N (2015). Oedipodinae (Acrididae: Orthoptera) of Azad Jammu and Kashmir, Pakistan. Pakistan J Zool 47: 1067-1076.

16. Gadagkar R, Bhagavan S, Malpe R \& Vinutha $C$ (1990). On reconfirming the evidence for pre-imaginal caste bias in a primitively eusocial wasp. Proc. Indian Acad. Sci. Anim. Sci 99: 141150.

17. Sultana R, Yawar S \& Wagan MS (2013). Orthopterian Biodiversity of Desert (Thar) Sindh Pakistan. Pak J. Zool 45: 299-304.

18. Hochkirch A., Adorf F. 2007. Effects of prescribed burning and wildfires on Orthoptera in Central European peat bogs. Environ Conserv 34: 225-235

19. Vickery VR \& Kevan DC (1983). A Monograph of the Orthopteroid insects of Canada and adjacent regions. Psyche 9 Memoirs of the Lyman
Entomological Museum and Research Laboratory 13(1): 1-679.

20. Wagan MS (2008). Preliminary studies on long horned grasshopper (Tettigonioidea) of Sindh. Pakistan Congr Zool 28: 69.

21. Bughio BA (2012). Taxonomy of the Band winged grasshopper (Oedipodinae: Acrididae: Acridoidea: Orthoptera) of Pakistan. PhD thesis. University of Sindh, Pakistan.

22. Drish VM (1961). A preliminary revision of the families and subfamilies of Acridoidae (Orthoptera: Insecta). $B$ ulletin of British Museum (Natural History) Entomology 10: 351-419.

23. Ritchie J (1982). A taxonomic Revision of the genus Gastrimargus Saussure (Orthoptera: Acrididae). Bulletin of British Museum (Natural History) Entomology 44: 293-329

24. Mason JB (1973). A revision of the genera Hieroglyphus Krauss, Parahier oglyphus Carl and Hieroglyphodes Uvarov (Orthoptera: Acridiodea). Bulletin of British Museum (Natural History) Entomology 28(7): 509-560.

25. Suhail A (1994). Taxonomic studies on Acridoidea (Orthoptera) of Pakistan. PhD Thesis. Department of Agriculture Entomology, University of Agriculture Faisalabad, Pakistan, 343pp.

26. Mahmood K (1995). Taxonomic studies of Acridoidea (Orthoptera) of Azad Jammu and Kashmir. PhD Thesis. Department of Entomology, University of Agriculture Faisalabad, Pakistan.

27. Bie-Bienko GY \& Mischenko LL (1951). Locust and Grasshoppers of USSR and Adjacent Countries. Pt I \& II, Monson, Jerusalem, 691pp.

28. Kirby WF (1914). Orthoptera (Acrididae). Faun a of British India including Ceylon and Burma. Taylor and Francis, London, 276pp. 
29. Eades DC, Otte D, Cigliano MM \& Braun H (2011). Orthoptera Species File. Version 5.0/5.0. [May 2013]. <http://Orthoptera.SpeciesFile.org>.

30. Shannon CE \& Weaver W (1949). The Mathematical Theory of Communication. Universityof Illinois Press, Urbana.

31. Sun T, LiuZY, QinLP\& Long RJ (2015). Grasshopper (Orthoptera: Acrididae) Community Composition in the Rangeland of the Northern Slopes of the Qilian Mountains in Northwestern China. $J$ of Insect Sci $5(1)$, 6. http://doi.org/10.1093/jisesa/ieu171

32. Evans EW (1988). Grasshopper (Insecta: Orthoptera: Acrididae) assemblages of Tall grass prairie: influences of fire frequency, topography, and vegetation. Canadian $J$ of Zool 7: 1495-1501.

33. Fielding DJ \& Defoliart MA (2008). Grasshopper (Orthoptera: Acrididae) community composition and ecological disturbance on southern Idaho rangeland. Envir Ento 1(22): 7181.

34. Joern A (2004). Variation in grasshopper (Acrididae) densities in response to fire frequency and bison grazing in tall grass prairie. J Enir Ento 6(33):1617- 1625.

35. Mahmood M, Abbas K \& Shah WH (2004). A Preliminary Study of Grasshoppers (Acrididae: Orthoptera) of Baltistan, Azad Jammu \& Kashmir, Pakistan. Pak J Zool 36(1): 21-25.
36. Sultana R, Wagan AS \& Wagan MS (2012). Effects of Macro-Parasitic mite Eutrombidium trigonum (Hermann) on the life History Characteristics of Hieroglyphus species from Sindh, Pakistan. African J of Microbio Res 6(19): 4158-4163.

37. Riffat S \& Wagan MS (2007). The effect of Food Plants on Growth, Fecundity and Survivability of Grasshopper Hieroglyphus nigrorepletus Bolivar (Orthoperta: Acrididae) a Major Paddy pest in Pakistan. Pak J of Biol Sci 7: 12821286.

38. Habtewold $\mathrm{T}$ \& Landin J (1992). Composition and structure of Orthoptera fauna in cereal crops in Ethiopia. Bulletin Ento Res 82: 29-39.

39. Akhtar MH, Usmani MK, Nayeem MR \& Kumar H (2012). Species Diversity and abundance of Grasshopper fauna (Orthoptera) in rice Ecosystem. Annals of Biol Rese 3(5): 2190-2193.

40. Mukhtar G, Nawaz M, Nawaz Y and Kakar A (2010). Biodiversity and Occurrence of Grasshoppers (Acrididae: Orthoptera) of Quetta Division Balochistan. Pakistan J Zool 42(1): 8791.

41. Nazir N, Mehmood K, Ashfaq M \& Rahim J (2014). Morphological and molecular identification of acridid grasshoppers(Acrididae: Ortho ptera) from Poonch division, Azad Jammu Kashmir, Pakistan. $J$ of Threatened Taxa 6(3): 5544-5552. 